\title{
Article \\ Elicitation of Medicinal Plants In Vivo-Is It a Realistic Tool? The Effect of Methyl Jasmonate and Salicylic Acid on Lamiaceae Species
}

\author{
Wafae Kandoudi * (D), Péter Radácsi, Beáta Gosztola and Éva Zámboriné Németh *(D) \\ Department of Medicinal and Aromatic Plants, Hungarian University of Agriculture and Life Sciences, Villányi \\ St. 29-35, 1118 Budapest, Hungary; Radacsi.Peter@uni-mate.hu (P.R.); gosztola.beata@uni-mate.hu (B.G.) \\ * Correspondence: Kandoudi.Wafae@phd.uni-mate.hu (W.K.); Zamborine.Nemeth.Eva@uni-mate.hu (É.Z.N.)
}

check for

updates

Citation: Kandoudi, W.; Radácsi, P.; Gosztola, B.; Zámboriné Németh, É. Elicitation of Medicinal Plants In Vivo-Is It a Realistic Tool? The Effect of Methyl Jasmonate and Salicylic Acid on Lamiaceae Species. Horticulturae 2022, 8, 5. https:// doi.org/10.3390/horticulturae8010005

Academic Editor: Bimal

Kumar Ghimire

Received: 15 November 2021

Accepted: 17 December 2021

Published: 22 December 2021

Publisher's Note: MDPI stays neutral with regard to jurisdictional claims in published maps and institutional affiliations.

Copyright: () 2021 by the authors. Licensee MDPI, Basel, Switzerland. This article is an open access article distributed under the terms and conditions of the Creative Commons Attribution (CC BY) license (https:// creativecommons.org/licenses/by/ $4.0 /)$.

\begin{abstract}
Salicylic acid (SA) and methyl jasmonate (MeJa) are prominent phytohormones that are involved in stress reactions. Both compounds may influence the biosynthesis of secondary compounds; however, scientific experiments in vivo are rare and contradictive. This paper reports on a study on the elicitation of volatiles and total phenolics (TPC) by MeJa and SA. The subjects were four Lamiaceae species studied in open field conditions in Budapest (Hungary). According to the results, both elicitors provoked specific responses in each plant species depending on the dosage applied and the parameter studied; $2 \mathrm{mM}$ of SA stimulated essential oil (EO) accumulation in marjoram and peppermint, while in hyssop $0.1 \mathrm{mM}$ was optimal. MeJa proved to be effective only in marjoram and in basil. In marjoram, cis-sabinene hydrate was decreased and in hyssop, isopinocamphone was increased by both dosages of SA. In peppermint, pulegone content was reduced by $2 \mathrm{mM} \mathrm{SA}$, but no significant change of the major components of basil EO was detected. SA was successful in increasing TPC and antioxidant activity (AC) in three of the experimental species, but not in hyssop. In marjoram, only $0.1 \mathrm{mM}$ induced TPC and eventually AC, while in peppermint and basil both dosages of SA were effective. Optimalisation of the treatments is suggested in further in vivo experiments.
\end{abstract}

Keywords: elicitor; medicinal and aromatic plants; essential oil; phenolic content; antioxidant capacity

\section{Introduction}

The Lamiaceae family consists of a large number of medicinal and aromatic plants (MAP); annual or perennial; with a worldwide distribution [1]. They are widely used in traditional medicine, in the perfumery, pharmaceutical, and cosmetics industries; and as flavoring agents in gastronomy, all due to their bioactive secondary compounds [2]. Some of the most widely used and popular species of this family are marjoram, peppermint, hyssop, and basil.

Sweet marjoram (Origanum majorana L.); also known as Majorana hortensis Moench; is a popular Mediterranean species traditionally used to treat gastrointestinal disturbances, cough, bronchial diseases, and headaches [3,4]. The herb contains volatile compounds, characteristically sabinene and terpinene derivatives. Like other species of the genus, marjoram is also rich in phenolics and caffeic acid derivatives, but ascorbic acid and carotenoids have been detected as well $[5,6]$.

Peppermint (Mentha piperita L.) is a flavor-rich species of dark green leaves, a hybrid of spearmint (Mentha spicata) and water mint (Mentha aquatica). It is used as a flavoring agent and is a key ingredient in herbal infusions [7]. Fresh or dried leaves of peppermint are rich in essential oils (EO) with the main component being 1-menthol; furthermore, they contain phenolic compounds, such as rosmarinic acid, hesperidin, and luteolin-7-O-rutinoside [8,9].

Hyssop (Hyssopus officinalis L.), originating from eastern Asia, has been heavily used both as a culinary and as a medicinal herb, similar to the related species mentioned above, 
the main active ingredient is $\mathrm{EO}$, with pinocamphone, $\beta$-pinene and pinocarvone as the main compounds. Besides, the drug is rich in caffeic acid derivatives [10,11].

Sweet basil (Ocimum basilicum L.) is one of the most popular species used in food as a fresh or dried herb. The attractive aroma is due to the volatile components, among which linalool, camphor, and methyl-chavicol are present in the highest ratios, depending on the chemotype. The health-promoting effects are attributed to the high phenolic content, including rosmarinic acid and caffeic acid, with its derivatives [12,13].

In the recent past, several strategies have been studied which increase the production of secondary metabolites (SMs) of MAPs, including elicitation. The application of chemical elicitors on plants triggers defense reactions, which might lead to an elevated concentration of different SMs [14]. Among different elicitors, salicylic acid (SA) and methyl jasmonate (MeJa) are well known phytohormones involved in biotic and abiotic stress reactions $[15,16]$. When applied exogenously, both compounds could induce the synthesis of SMs and subsequently enhance the biological activities both in cell plant cultures and in vivo plants $[17,18]$. However, scientific data on in vivo applications are much rarer and more contradictive, which indicates the need for further research.

This paper describes the effect of MeJa and SA in different concentrations, studied on four Lamiaceae species: marjoram, peppermint, hyssop, and basil. Emphasis was placed on the accumulation and composition of their EO, phenolic content and antioxidant properties.

\section{Materials and Methods}

\subsection{Experimental Site, Plant Material and Treatments}

The experiments were conducted at the Experimental Station of the University of Agricultural and Life Sciences (MATE), in Budapest, Hungary (47.398820, 19.149270). The experimental plant material, with its origin, is summarized in Table 1.

Table 1. Plant material and its origin.

\begin{tabular}{ccc}
\hline Species & Taxon & Origin \\
\hline Hyssopus officinalis & population & seed collection in cultivated stand, Meran, Italy \\
Origanum majorana & variety 'Magyar' & superelite seeds stock of MATE \\
Mentha piperita & variety 'Mexian' & stolons from mother plantation of MATE \\
Ocimum basilicum & variety 'Genovese' & gene bank accession of MATE \\
\hline
\end{tabular}

Marjoram and basil were propagated by seed sowing at the beginning of April 2020 in a greenhouse, and the well-developed seedlings were planted into the open field in early June. In the case of the perennial species, we used two-year-old stands. The hyssop was propagated from seedlings and the peppermint was done vegetatively, via stolons at the end of March in the previous year. The experiments were arranged in a completely randomized block design with a plot size of $10 \mathrm{~m}^{2}$ in three replications for each treatment. The soil characteristics and temperature data during the experimental period are summarized in Table 2 and Figure 1 respectively.

Table 2. The soil composition of the experimental plot.

\begin{tabular}{|c|c|c|c|c|c|c|c|c|c|c|}
\hline Measured Parameter & $\begin{array}{c}\mathrm{pH} \\
\mathrm{H}_{2} \mathrm{O}\end{array}$ & $\begin{array}{c}\text { Humus } \\
\text { Content } \\
\%\end{array}$ & $\begin{array}{c}\text { Lime } \\
\text { Content } \\
\%\end{array}$ & $\mathbf{K}_{\mathrm{A}}$ & $\begin{array}{c}\mathrm{NO}_{2}+ \\
\mathrm{NO}_{3}-\mathrm{N} \\
\mathrm{mg} / \mathrm{kg}\end{array}$ & $\begin{array}{c}\mathrm{P}_{2} \mathrm{O}_{5} \\
\mathrm{mg} / \mathrm{kg}\end{array}$ & $\begin{array}{c}\mathrm{K}_{2} \mathrm{O} \\
\mathrm{mg} / \mathrm{kg}\end{array}$ & $\begin{array}{c}\mathrm{Zn} \\
\mathrm{mg} / \mathrm{kg}\end{array}$ & $\begin{array}{c}\mathrm{Mg} \\
\mathrm{mg} / \mathrm{kg}\end{array}$ & $\begin{array}{c}\mathrm{Mn} \\
\mathrm{mg} / \mathrm{kg}\end{array}$ \\
\hline Experimental station soil & 7.82 & 2.84 & 0.34 & 25 & 6.93 & 412.89 & 245.54 & 4.09 & 131.78 & 25.64 \\
\hline
\end{tabular}

We started the treatments two weeks before the optimal harvesting stage (full flowering) of each species. The plants were sprayed with MeJa and SA supplied by Sigma-Aldrich (Schnelldorf, Germany) and Kévés Béla Kft. (Soltvadkert, Hungary) respectively in two dosages: 0.1 and $2.0 \mathrm{mM}$, dissolved in water. The control plots were sprayed only with 
water. All solutions were sprayed onto the aboveground shoots, uniformly distributed with a hand sprayer (approximately $50 \mathrm{~mL}$ per plant). The treatments were applied twice with an interval of one week (Table 3). One week after the second treatment, sampling of each species was carried out according to our previous research experiences. The aerial parts of the plants were harvested by cutting the plants at approximately $10 \mathrm{~cm}$ above the soil surface. The samples were air-dried in shade under ambient temperature.

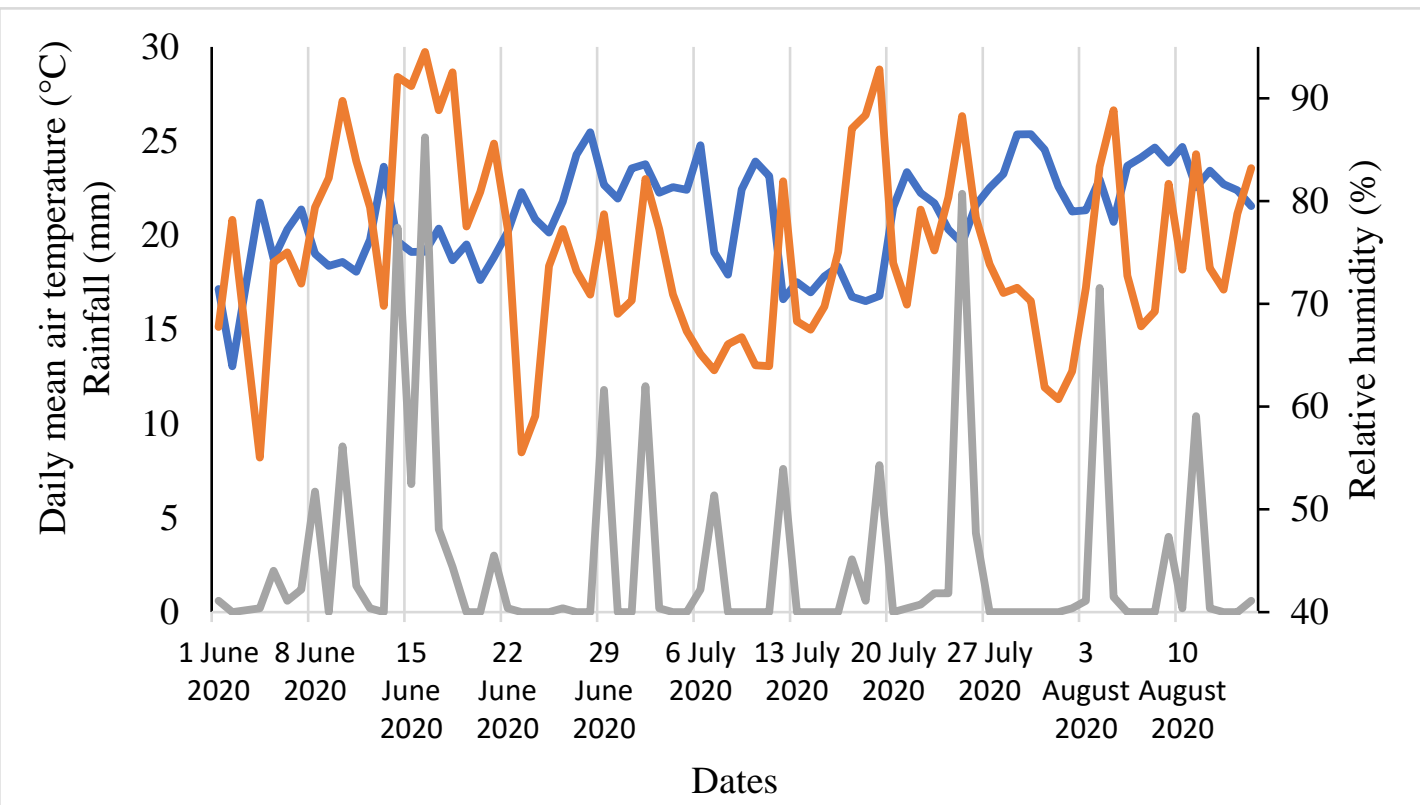

Daily mean air temperature $\left({ }^{\circ} \mathrm{C}\right) \quad$ Rainfall $(\mathrm{mm})$
Relative humidity $(\%)$

Figure 1. Daily mean air temperature $\left({ }^{\circ} \mathrm{C}\right)$, rainfall $(\mathrm{mm})$, and relative humidity $(\%)$ of the experimental field in summer 2020.

Table 3. Treatment and harvesting times of the experimental species.

\begin{tabular}{cccc}
\hline Plant & 1st Treatment & 2nd Treatment & Harvesting \\
\hline Hyssop & 12 June 2020 & 19 June 2020 & 26 June 2020 \\
Peppermint & 19 June 2020 & 26 June 2020 & 2 July 2020 \\
Marjoram & 26 June 2020 & 2 July 2020 & 10 July 2020 \\
Basil & 29 July 2020 & 5 August 2020 & 13 August 2020 \\
\hline
\end{tabular}

\subsection{Chemical Analysis}

\subsubsection{EO Content}

After drying the plants for 2 weeks, we placed them in the laboratory. Leaves were separated from stem parts, and they were used in three replicates for EO distillation; $20 \mathrm{~g}$ dried material from each sample was hydro-distilled in a Clevenger type apparatus using $500 \mathrm{~mL}$ of water for $1.5 \mathrm{~h}$ for peppermint and $2 \mathrm{~h}$ for the other species, according to the method recommended by the VII Hungarian Pharmacopoeia. The oils were collected, and traces of water were removed with anhydrous sodium sulfate. Then, the extracts were separated with a syringe filter and stored in an airtight vial in a refrigerator at $4{ }^{\circ} \mathrm{C}$ before analysis. 


\subsubsection{EO Composition}

The identification of the active components of the EO was performed by GC-MS. We used two devices: an Agilent Technologies 6890N instrument equipped with HP-5MS capillary column (5\% phenyl, 95\% dimethyl polysiloxane, length: $30 \mathrm{~m}$, film thickness: $0.25 \mathrm{~mm}$ i.d. $\times 0.25 \mu \mathrm{m})$; and an Agilent Technologies MS 5975 inert mass selective detector, both supplied by Agilent technologies international Sàrl (Rolle, Switzerland). The carrier gas was helium $\left(1 \mathrm{~mL} \mathrm{~min}{ }^{-1}\right)$. The temperature during the analysis was scheduled at $60{ }^{\circ} \mathrm{C}$ initially, then raised by a rate of $3{ }^{\circ} \mathrm{C} / \mathrm{min}$ up to $240{ }^{\circ} \mathrm{C}$; the final temperature remained for $5 \mathrm{~min}$. The injector and detector temperatures were $250^{\circ} \mathrm{C}$. Split ratio: 30:1; $10 \mu \mathrm{L}$ of EO was diluted with $\mathrm{n}$-hexane to $1 \mathrm{~mL}$ and from this, the injected quantity was $0.2 \mu \mathrm{L}$. Ionization energy was $70 \mathrm{eV}$. The MS was recorded in full scan mode, which revealed the total ion current (TIC) chromatograms (mass range m/z 50-500 $\mu \mathrm{ma}$ ). The identification of the EO components was based on the comparison of their linear retention indices, which were calculated using the generalized equation of Van Den Dool and Kratz [19] with literature data, and by matching recorded mass spectra with those in mass spectral library references (NIST MS Search 2.0 library, Wiley 275) and a mass spectra library [20].

\subsubsection{Total Phenolic Content (TPC)}

For the determination of the TPC, $1 \mathrm{~g}$ powdered dried plant material was obtained by grinding the dry leaves and sifting them with a $500 \mu \mathrm{m}$ diameter sieve. We then added $100 \mathrm{~mL}$ boiling distilled water (used as a solvent), which was extracted after $24 \mathrm{~h}$. Finally, the extracts were filtered and stored frozen awaiting further measurements. The quantification of total phenolic content was determined by the modified method of Singleton and Rossi [21]. The sample solution of $0.5 \mathrm{~mL}$ was placed in a test tube, and then $2.5 \mathrm{~mL}$ Folin-Ciocalteau's reagent $(10 \mathrm{v} / \mathrm{v} \%)$ was added. After $1 \mathrm{~min}$ of incubation, $2 \mathrm{~mL}$ of sodium carbonate $(700 \mathrm{mM})$ was added. The absorbance was measured at $760 \mathrm{~nm}$ in a Thermo Evolution 201 spectrophotometer after a $5 \mathrm{~min}$ incubation period in hot water $\left(50{ }^{\circ} \mathrm{C}\right)$. Gallic acid (300 mM) was used as the chemical standard for calibration. The total phenolic content of the sample was expressed as $\mathrm{mg}$ of gallic acid equivalents per $\mathrm{g}$ of dry weight of extract (GAE mg.g ${ }^{-1}$ d.w.). A blank was prepared which contain distilled water instead of extract. The measurements were carried out in three replications.

\subsubsection{Antioxidant Capacity (AC)}

The antioxidant capacity was determined by the application of the ferric reducing antioxidant power (FRAP) assay developed by Benzie and Strain [22], with a few modifications. FRAP reagent was prepared fresh, in order to contain three things: sodium acetate buffer ( $\mathrm{pH} 3.6$ ), TPTZ (2,4,6-tripiridil-s-triazin) in $\mathrm{HCl}$, and $\mathrm{FeCl}_{3} \cdot 6 \mathrm{H}_{2} \mathrm{O}$ solution $(20 \mathrm{mmol} / \mathrm{L})$, in the proportion 10:1:1 $(\mathrm{v} / \mathrm{v} / \mathrm{v}) ; 10 \mu \mathrm{L}$ of the previously extracted test sample was added to $1.5 \mathrm{~mL}$ of acting FRAP reagent and $40 \mu \mathrm{L}$ distilled water. The absorbance of the solution was then measured at $593 \mathrm{~nm}$ after 5 min using the above-mentioned spectrophotometer. A blank was made to contain distilled water instead of the sample and ascorbic acid was used as a positive control. FRAP values of samples were calculated from the standard curve equation and expressed as $\mathrm{mg}$ ascorbic acid equivalent (AAE) $\cdot \mathrm{g}^{-1}$ of dry extract.

\subsubsection{Statistical Analysis}

Data were evaluated using means, standard deviations, and one-way analysis of variance using IBM SPSS Statistics 25. Normality of the residuals was proved by the Shapiro-Wilk test, the homogeneity of variances was tested by Levene's method, and finally, the control and treated samples were separated by Tukey's post hoc tests if homogeneity assumption was satisfied, and the separations were modified by Games-Howell's post hoc tests of homogeneity of variances was violated. The $p$-value less than 0.05 was considered statistically significant. 


\section{Results and Discussion}

\subsection{Essential Oil Content}

Our results showed different results for the EO depending on the elicitor, its dosage, and the plant species. Figure 2 represents the EO content expressed by mL/100 g of dry material.
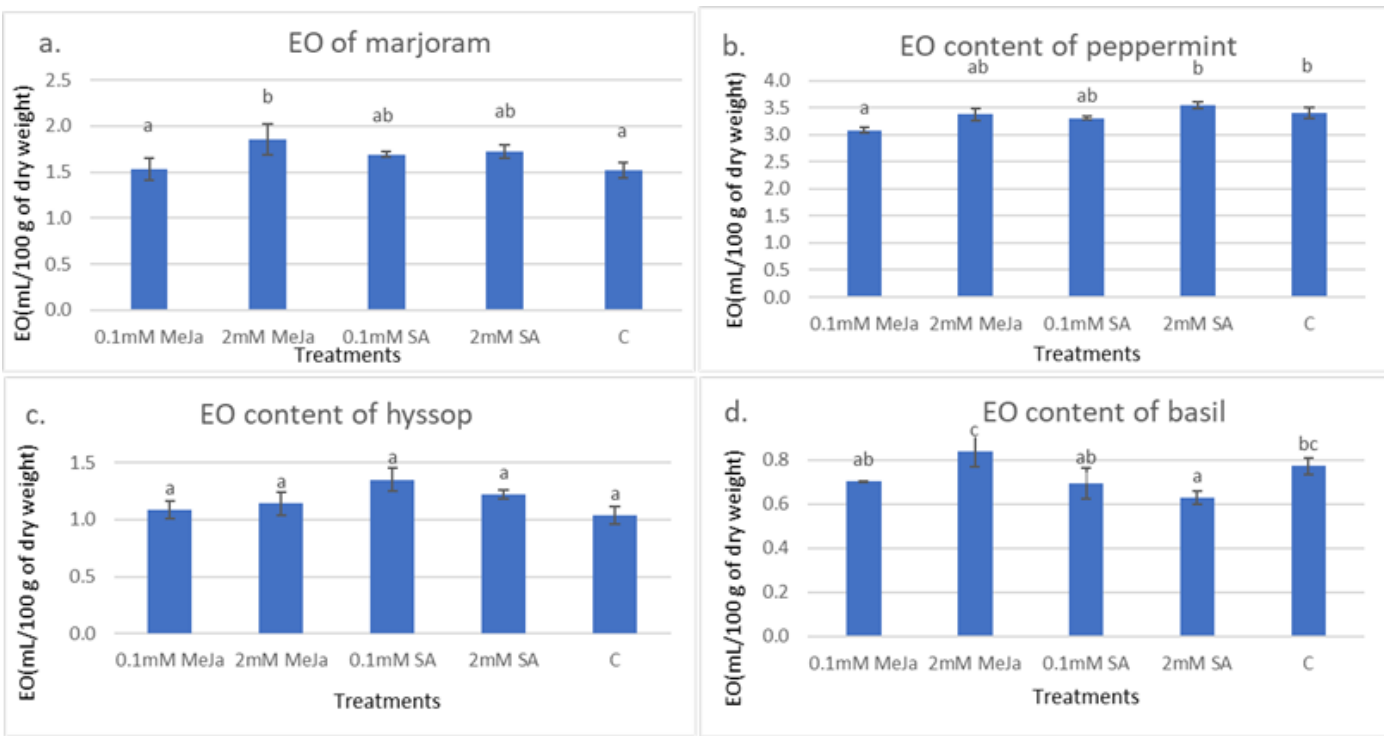

Figure 2. The effect of MeJa and SA on the EO content of the subject plants; (a) marjoram, (b) peppermint, (c) hyssop, and (d) basil; Data are expressed as means \pm SD; means with different letters are significantly different $(p<0.05)$.

In marjoram, higher dosages both of MeJa and SA were significantly more effective than lower dosages, but none of them differed statistically from the control, except for the $2 \mathrm{mM}$ of MeJa. The latter and $2 \mathrm{mM}$ of SA increased the EO content by $23 \%$ and $15 \%$ respectively.

In peppermint, similarly, the higher dosage of SA resulted in a slight increase of the EO content, while the lower $(0.1 \mathrm{mM})$ dosage was not effective. However, treatments with MeJa seem to stop the accumulation of volatiles, interestingly. Especially the $0.1 \mathrm{mM}$ treatment caused a significant decrease.

Hyssop also showed greater sensitivity to SA than to MeJa. The highest EO content $(0.35 \mathrm{~mL} / 100 \mathrm{~g}$ d.w.) was measured in the samples sprayed with $0.1 \mathrm{mM}$ of SA. The higher dosage of it also elevated EO content but was not significant. Spraying with MeJa in either concentration had no significant elicitor effect on the volatiles of this species.

Basil showed a distinct reaction to the treatments compared to the previously mentioned species, as the EO content dropped in consequence of each treatment, except for the $2 \mathrm{mM}$ of MeJa. Especially the higher dosage of SA resulted in a significant decrease of the volatile accumulation, by approximately $20 \%$.

Our findings partly agree with a few studies where the application of different dosages of SA or MeJa/JA did not have a significant difference on the accumulation of EO in other Lamiaceae species, such as summer savory (Satureja hortensis) and thyme (Thymus daenensis Celak) $[23,24]$.

Yadegari et al. [25] showed that a low dosage of SA $(0.1 \mathrm{mM})$ failed to enhance the EO production of sage (Salvia officinalis) in contrast to higher dosages. At the same time, elicitation with $0.1 \mathrm{mM}$ of MeJa was effective for increasing the EO percentage in anise hyssop (Agastache foeniculum) [26]. 


\subsection{Essential Oil Composition}

The results of GC-MS analysis of marjoram in Table 4 revealed the presence of 15 compounds reaching $97.4-98.6 \%$ of the total area percentages were identified in the EO. in each sample, cis-sabinene hydrate and terpinen-4-ol were detected as major components, however, their ratios changed according to the treatments.

Table 4. The chemical composition of the EO of marjoram.

\begin{tabular}{|c|c|c|c|c|c|c|c|}
\hline \multirow[b]{2}{*}{ Component } & \multicolumn{7}{|c|}{ Elicitors } \\
\hline & $\mathbf{R I}^{1}$ & 0.1 mM Meja & $2 \mathrm{mM}$ MeJa & $0.1 \mathrm{mM}$ SA & $2 \mathrm{mM} S A$ & $C^{2}$ & Sign. $^{3}$ \\
\hline Sabinene & 976 & $3.42^{\mathrm{a}}$ & $3.19^{a}$ & $4.52^{\mathrm{a}}$ & $3.77^{\mathrm{a}}$ & $3.52^{\mathrm{a}}$ & ns \\
\hline$\beta$-Myrcene & 995 & $0.76^{\mathrm{a}}$ & $0.70^{\mathrm{a}}$ & $1.03^{\mathrm{a}}$ & $0.86^{\mathrm{a}}$ & $0.80^{\mathrm{a}}$ & ns \\
\hline$\alpha$-Terpinene & 1018 & $2.24^{\mathrm{a}}$ & $2.29^{a}$ & $2.87^{\mathrm{a}}$ & $2.75^{\mathrm{a}}$ & $2.12^{\mathrm{a}}$ & ns \\
\hline$\beta$-Phellandrene & 1029 & $2.18^{a}$ & $2.22^{a}$ & $2.48^{\mathrm{a}}$ & $2.19^{a}$ & $2.08^{a}$ & ns \\
\hline$\gamma$-Terpinene & 1056 & $4.96^{\mathrm{a}}$ & $4.83^{\mathrm{a}}$ & $5.47^{\mathrm{a}}$ & $5.48^{\mathrm{a}}$ & $4.30^{\mathrm{a}}$ & ns \\
\hline trans-Sabinene hydrate & 1070 & $7.10^{\mathrm{a}}$ & $6.99^{a}$ & $6.65^{\mathrm{a}}$ & $7.18^{a}$ & $6.57^{\mathrm{a}}$ & ns \\
\hline$\alpha$-Terpinolene & 1085 & $1.12^{\mathrm{a}}$ & $1.63^{\mathrm{a}}$ & $1.29^{\mathrm{a}}$ & $1.25^{\mathrm{a}}$ & $0.98^{\mathrm{a}}$ & ns \\
\hline cis-Sabinene hydrate & 1096 & $43.54^{\mathrm{ab}}$ & $42.74^{\mathrm{ab}}$ & $37.77^{\mathrm{a}}$ & $40.99^{a}$ & $48.24^{b}$ & $*$ \\
\hline cis-p-Menth-2-en-1-ol & 1126 & $0.96^{\mathrm{a}}$ & $1.09^{\mathrm{a}}$ & $1.07^{\mathrm{a}}$ & $1.11^{\mathrm{a}}$ & $0.85^{\mathrm{a}}$ & ns \\
\hline Terpinen-4-ol & 1175 & $14.02^{a b}$ & $13.28^{a b}$ & $12.67^{a b}$ & $14.99^{b}$ & $11.62^{\mathrm{a}}$ & * \\
\hline$\alpha$-Terpineol & 1189 & $4.14^{\mathrm{a}}$ & $4.56^{\mathrm{a}}$ & $4.52^{\mathrm{a}}$ & $4.57^{\mathrm{a}}$ & $4.70^{\mathrm{a}}$ & ns \\
\hline trans-Sabinene hydrate acetate & 1247 & $2.48^{\mathrm{a}}$ & $2.76^{\mathrm{a}}$ & $3.96^{\mathrm{a}}$ & $3.95^{\mathrm{a}}$ & $2.47^{\mathrm{a}}$ & ns \\
\hline Linalyl acetate & 1250 & $3.00^{\mathrm{a}}$ & $3.36^{\mathrm{ab}}$ & $3.44^{\mathrm{ab}}$ & $3.51^{\mathrm{ab}}$ & $4.27^{b}$ & $* *$ \\
\hline$\beta$-Caryophyllene & 1420 & $3.88^{b}$ & $3.69 \mathrm{ab}$ & $4.14^{\mathrm{b}}$ & $3.11^{\mathrm{a}}$ & $3.22^{a}$ & * \\
\hline Bicyclogermacrene & 1497 & $3.63^{b}$ & $3.63^{b}$ & $4.20^{b}$ & $2.26^{\mathrm{a}}$ & $2.89^{\mathrm{a}}$ & * \\
\hline Monoterpenes & & $89.91^{a b}$ & $89.61^{a b}$ & $87.75^{\mathrm{a}}$ & $92.60^{\mathrm{b}}$ & $92.52^{b}$ & * \\
\hline Sesquiterpenes & & $7.51^{\mathrm{ab}}$ & $7.32^{a b}$ & $8.33^{b}$ & $5.38^{a}$ & $6.11^{\mathrm{ab}}$ & * \\
\hline Total & & 97.42 & 96.92 & 96.08 & 97.98 & 98.63 & \\
\hline
\end{tabular}

Notes: ${ }^{1}$ Retention indices; ${ }^{2}$ control sample; ${ }^{3}$ the level of significance: $n s=$ not significant, ${ }^{*}=$ significance level at $5 \%,{ }^{* *}=$ significance level at $1 \%$; Values designated by the different letters are significantly different.

The concentration of the sabinene hydrate isomers decreased as a consequence of all treatments, among which significant differences of $22 \%$ and $16 \%$ were detected in the ratio of cis-sabinene hydrate due to the spraying with $0.1 \mathrm{mM}$ and $2 \mathrm{mM}$ of SA, respectively. At the same time, the ratio of terpinen-4-ol was increased by all treatments and significant (30\%) elevation was registered at the higher dosage of SA. Furthermore, the two sesquiterpenes identified in the samples both increased due to the spraying of both dosages of MeJa and $0.1 \mathrm{mM}$ of SA. The highest concentration of beta-caryophyllene was obtained by $0.1 \mathrm{mM}$ SA, while the same dosage increased bicyclogermacrene by approximately $45 \%$. As a result, the ratio of total sesquiterpenes in the oil was elevated, too.

The findings about the elicitation of marjoram with SA in Egypt were partly in accordance with ours: the treatment of $0.1 \mathrm{mM}$ of SA increased the ratio of both cis-sabinene hydrate and terpinen-4-ol in the EO [27]. Interestingly, elicitation by the application of compost (Nitrogen-fixers + Bacillus circulans) had the same results as those of our study: ratio of the sabinene hydrate decreased, but that of terpinen-4-ol was elevated [28].

The statistical analysis of the EO composition of peppermint in Table 5 revealed that in the ratio of the main compounds menthol and menthone, there are no significant differences in the treated samples compared with the control (Table 5). Only the ratio of pulegone was reduced after spraying $2 \mathrm{mM}$ of SA by approximately $43 \%$, which seems to be advantageous considering the EU regulation on limits for pulegone and menthofuran [29]. Yet, in another experiment, $0.1 \mathrm{mM}$ of SA was able to increase the menthol and the menthyl acetate concentration significantly, when applied exogenously to peppermint [30]. On the other hand, it appears that a physical elicitor, such as UV-B may have more effect on the peppermint EO quality, where UV radiation greatly increased methofuran, menthyl acetate, and menthone but significantly decreased the menthol level. This can be a serious drawback due to the quality requirements and importance of the menthol compound in the 
industry [31]. In our experiment, the treatments likewise did not cause significant changes in the total mono and sesquiterpene ratio.

Table 5. The chemical composition of the EO of peppermint.

\begin{tabular}{|c|c|c|c|c|c|c|c|}
\hline \multirow[b]{2}{*}{ Component } & \multicolumn{7}{|c|}{ Elicitors } \\
\hline & RI $^{1}$ & $0.1 \mathrm{mM}$ Meja & $2 \mathrm{mM}$ MeJa & $0.1 \mathrm{mM} S A$ & $2 \mathrm{mM} \mathrm{SA}$ & $\mathrm{C}^{2}$ & Sign. $^{3}$ \\
\hline Limonene & 1029 & $5.33^{\mathrm{a}}$ & $5.23^{\mathrm{a}}$ & $6.015^{\mathrm{a}}$ & $6.145^{\mathrm{a}}$ & $5.51^{\mathrm{a}}$ & ns \\
\hline 1,8-Cineol & 1034 & $4.27^{\mathrm{a}}$ & $3.94^{\mathrm{a}}$ & $4.70^{\mathrm{a}}$ & $4.98^{\mathrm{a}}$ & $4.28^{\mathrm{a}}$ & ns \\
\hline$\gamma$-Terpinene & 1056 & $0.90^{\mathrm{a}}$ & $1.03^{\mathrm{a}}$ & $0.94^{\mathrm{a}}$ & $0.88^{\mathrm{a}}$ & $1.00^{\mathrm{a}}$ & ns \\
\hline Menthone & 1158 & $32.92^{\mathrm{a}}$ & $35.15^{\mathrm{a}}$ & $34.12^{\mathrm{a}}$ & $31.81^{\mathrm{a}}$ & $35.05^{a}$ & ns \\
\hline Menthofuran & 1168 & $7.56^{a}$ & $7.91^{\mathrm{a}}$ & $7.52^{\mathrm{a}}$ & $7.41^{\mathrm{a}}$ & $7.7^{\mathrm{a}}$ & ns \\
\hline Menthol & 1171 & $30.67^{\mathrm{a}}$ & $27.73^{a}$ & $29.46^{\mathrm{a}}$ & $31.02^{\mathrm{a}}$ & $27.79^{a}$ & ns \\
\hline Pulegone & 1236 & $1.80^{a b}$ & $2.06^{\mathrm{a}}$ & $1.44^{\mathrm{ab}}$ & $1.12^{b}$ & $1.96^{\mathrm{a}}$ & $*$ \\
\hline Piperitone & 1249 & $1.50^{\mathrm{a}}$ & $1.66^{\mathrm{a}}$ & $1.60^{\mathrm{a}}$ & $1.58^{\mathrm{a}}$ & $1.57^{\mathrm{a}}$ & ns \\
\hline Menthyl acetate & 1291 & $4.56^{\mathrm{a}}$ & $4.12^{\mathrm{a}}$ & $3.91^{\mathrm{a}}$ & $3.98^{\mathrm{a}}$ & $4.57^{\mathrm{a}}$ & ns \\
\hline Germacrene D & 1482 & $1.49^{\mathrm{a}}$ & $1.77^{\mathrm{a}}$ & $1.48^{\mathrm{a}}$ & $1.68^{\mathrm{a}}$ & $1.78^{\mathrm{a}}$ & ns \\
\hline Monoterpenes & & $89.53^{a}$ & $88.85^{\mathrm{a}}$ & $89.71^{\mathrm{a}}$ & $88.94^{\mathrm{a}}$ & $89.45^{\mathrm{a}}$ & ns \\
\hline Sesquiterpenes & & $1.49^{\mathrm{a}}$ & $1.77^{\mathrm{a}}$ & $1.48^{\mathrm{a}}$ & $1.68^{\mathrm{a}}$ & $1.78^{a}$ & ns \\
\hline Total & & 91.02 & 90.62 & 91.19 & 90.62 & 91.23 & \\
\hline
\end{tabular}

Notes: ${ }^{1}$ Retention indices; ${ }^{2}$ control sample; ${ }^{3}$ the level of significance: $n$ s $=$ not significant, ${ }^{*}=$ significance level at $5 \%$; Values designated by the different letters are significantly different.

The EO analysis of hyssop in Table 6 reveals that the ratio of $\beta$-phellandrene decreased significantly, by $46 \%$ with $0.1 \mathrm{mM} \mathrm{SA}$, however, the other treatments had no significant effects. Pentylbenzen and the main component isopinocamphone changed significantly due to the SA treatments. Their concentrations were elevated by $65 \%$ and $60 \%$ respectively when $0.1 \mathrm{mM}$ was applied, and by 39 and $28 \%$ with $2 \mathrm{mM}$ of SA. Interestingly, MeJA in $2 \mathrm{mM}$ concentration also elevated the ratios of the two compounds mentioned, by the same rate. The highest percentage of isopinocamphone was detected by $0.1 \mathrm{mM} \mathrm{SA}$, around $46 \%$ which may be advantageous considering the biological activities and wide use of this compound in perfumery and cosmetics [32,33]. SA was proven in other studies as well to be an important elicitor in increasing the main EO components in Achillea millefolium L. [34], Citrus aurantium L. [35] and Melissa officinalis [36]. Among sesquiterpenes, $\beta$-bisabolol was reduced after spraying $2 \mathrm{mM}$ of MeJa and $0.1 \mathrm{mM}$ of SA by $66 \%$ and $65 \%$, respectively. Overall, our results demonstrated a significant decrease in total sesquiterpenes with both dosages of MeJa and $0.1 \mathrm{mM}$ of SA, which contradicts a previous report that SA was able to stimulate the production of sesquiterpenes of hyssop [37].

Table 7 shows the result of the CG-MS analysis of the basil EO. It can be established that there was no significant difference for the major component linalool after the application of either of the elicitors. Among monoterpenes, only 1.8-cineole and iso-bornyl acetate changed significantly.

The first compound fell by $48 \%$ due to the $0.1 \mathrm{mM} \mathrm{SA}$ treatment, while the second one rose with $2.0 \mathrm{mM}$ MeJa but dropped with $2.0 \mathrm{mM} \mathrm{SA}$. Sesquiterpenes were characteristically more strongly affected. Both $\alpha$-guaiene and bicyclogermacrene levels were enhanced with the lower dosages of both elicitors; $0.1 \mathrm{mM}$ MeJa and $0.1 \mathrm{mM}$ SA increased $\alpha$-guaiene by $42 \%$ and $44 \%$, respectively; and bicyclogermacrene was $70 \%$ and $72 \%$, respectively. Besides, $0.1 \mathrm{mM}$ SA was able to increase $\beta$-elemene and bicyclogermacrene by $61 \%$ and $72 \%$, respectively. In parallel, the same lower dosage of MeJa reduced the ratio of trans$\alpha$-bergamotene compound by 38\%, while $0.1 \mathrm{mM} \mathrm{SA}$ increased it approximately by $24 \%$. Based on the above, the present result could not support the large increase $(113 \%)$ in the ratio of linalool following application of $0.1 \mathrm{mM}$ of $\mathrm{SA}$, a result which was registered in a previous experiment under hydroponic conditions [38].

Some other reports also indicate different results with basil, depending on the elicitor and the cultivar. A concentration of $0.5 \mathrm{mM}$ MeJa was proven to increase linalool level in the Genovese cultivar under salinity stress, while it decreased the same component in the 
Rubi cultivar [39]. Elicitation with copper sulfate in vitro significantly increased eugenol while inducing some compounds that were absent in the untreated samples [40]. In our study, no qualitative differences were detected in the spectrum. The total ratio was shifted significantly in the direction of monoterpenes due to the higher dosage of MeJa; and was shifted in the opposite direction by increasing the sesquiterpenes after the lower dosage of SA.

Table 6. The chemical composition of the EO of hyssop.

\begin{tabular}{|c|c|c|c|c|c|c|c|}
\hline \multirow[b]{2}{*}{ Component } & \multicolumn{7}{|c|}{ Elicitors } \\
\hline & $\mathrm{RI}^{1}$ & $0.1 \mathrm{mM}$ Мeja & $2 \mathrm{mM}$ MeJa & $0.1 \mathrm{mM}$ SA & $2 \mathrm{mM} S A$ & $C^{2}$ & Sign. $^{3}$ \\
\hline Sabinene & 976 & $1.04^{\mathrm{a}}$ & $1.06^{\mathrm{a}}$ & $1.05^{\mathrm{a}}$ & $0.89^{a}$ & $0.74^{\mathrm{a}}$ & ns \\
\hline$\beta$-Pinene & 981 & $5.20^{\mathrm{a}}$ & $5.74^{\mathrm{a}}$ & $5.93^{\mathrm{a}}$ & $4.47^{\mathrm{a}}$ & $3.44^{\mathrm{a}}$ & ns \\
\hline$\beta$-Myrcene & 995 & $2.56^{\mathrm{a}}$ & $2.03^{\mathrm{a}}$ & $1.49^{\mathrm{a}}$ & $1.65^{\mathrm{a}}$ & $2.14^{\mathrm{a}}$ & ns \\
\hline$\beta$-Phellandrene & 1029 & $14.46^{\mathrm{c}}$ & $10.61^{a b c}$ & $5.89^{a}$ & $8.12^{a b}$ & $12.85^{b c}$ & $*$ \\
\hline Linalool & 1097 & $1.12^{\mathrm{a}}$ & $1.05^{\mathrm{a}}$ & $1.00^{\mathrm{a}}$ & $0.99^{\mathrm{a}}$ & $1.10^{\mathrm{a}}$ & $\mathrm{ns}$ \\
\hline Benzene < pentyl-> & 1152 & $2.93^{b}$ & $3.18^{b c}$ & $3.78^{c}$ & $3.19^{b c}$ & $2.29^{a}$ & * \\
\hline Pinocarvone & 1166 & $0.18^{a}$ & $0.32^{b}$ & $0.37^{b}$ & $0.63^{c}$ & $0.14^{\mathrm{a}}$ & * \\
\hline Isopinocamphon & 1170 & $36.33^{b}$ & $37.30^{\mathrm{b}}$ & $46.36^{c}$ & $37.16^{\mathrm{b}}$ & $29.07^{\mathrm{a}}$ & * \\
\hline$\beta$-Bourbonene & 1383 & $0.44^{\mathrm{a}}$ & $0.35^{\mathrm{a}}$ & $0.50^{\mathrm{a}}$ & $0.37^{\mathrm{a}}$ & $0.32^{\mathrm{a}}$ & ns \\
\hline$\alpha$-Gurjunene & 1410 & $0.48^{a}$ & $0.37^{\mathrm{a}}$ & $0.52^{\mathrm{a}}$ & $0.62^{a}$ & $0.53^{a}$ & ns \\
\hline$\beta$-Caryophyllene & 1420 & $1.84^{\mathrm{a}}$ & $1.55^{\mathrm{a}}$ & $1.90^{\mathrm{a}}$ & $2.05^{\mathrm{a}}$ & $1.99^{\mathrm{a}}$ & ns \\
\hline Alloaromadendrene & 1462 & $1.89^{\mathrm{a}}$ & $1.51^{\mathrm{a}}$ & $1.97^{\mathrm{a}}$ & $2.29^{a}$ & $2.10^{\mathrm{a}}$ & ns \\
\hline Germacren-D & 1482 & $4.01^{\mathrm{a}}$ & $3.12^{\mathrm{a}}$ & $4.38^{\mathrm{a}}$ & $4.72^{\mathrm{a}}$ & $4.61^{\mathrm{a}}$ & ns \\
\hline Bicyclogermacrene & 1497 & $4.62^{\mathrm{a}}$ & $4.02^{\mathrm{a}}$ & $4.91^{\mathrm{a}}$ & $5.81^{\mathrm{a}}$ & $5.46^{\mathrm{a}}$ & ns \\
\hline Elemol & 1553 & $5.75^{\mathrm{a}}$ & $5.42^{\mathrm{a}}$ & $5.10^{\mathrm{a}}$ & $5.68^{a}$ & $6.03^{a}$ & ns \\
\hline Spathulenol & 1584 & $0.51^{\mathrm{a}}$ & $0.55^{\mathrm{a}}$ & $0.41^{\mathrm{a}}$ & $0.54^{\mathrm{a}}$ & $0.79^{a}$ & ns \\
\hline Caryophyllene-oxide & 1590 & $0.62^{a}$ & $0.83^{\mathrm{a}}$ & $0.47^{\mathrm{a}}$ & $0.69^{a}$ & $1.06^{\mathrm{a}}$ & ns \\
\hline cis-Isolongifolene & 1611 & $0.70^{\mathrm{a}}$ & $0.94^{\mathrm{a}}$ & $0.58^{\mathrm{a}}$ & $1.01^{\mathrm{a}}$ & $1.28^{\mathrm{a}}$ & ns \\
\hline$\gamma$-eudesmol & 1630 & $1.69^{\mathrm{a}}$ & $1.77^{\mathrm{a}}$ & $1.43^{\mathrm{a}}$ & $1.64^{\mathrm{a}}$ & $2.73^{\mathrm{a}}$ & ns \\
\hline Tau-muurolol & 1647 & $0.89^{a}$ & $1.32^{\mathrm{a}}$ & $0.70^{\mathrm{a}}$ & $1.25^{\mathrm{a}}$ & $2.18^{a}$ & ns \\
\hline$\beta$-eudesmol & 1653 & $1.33^{\mathrm{a}}$ & $1.52^{\mathrm{ab}}$ & $0.99^{\mathrm{a}}$ & $1.31^{\mathrm{a}}$ & $2.21^{b}$ & * \\
\hline$\alpha$-eudesmol & 1656 & $1.60^{\mathrm{a}}$ & $2.37^{\mathrm{a}}$ & $1.11^{\mathrm{a}}$ & $1.57^{\mathrm{a}}$ & $2.40^{\mathrm{a}}$ & ns \\
\hline$\beta$-bisabolol & 1671 & $4.53^{\mathrm{ab}}$ & $4.22^{\mathrm{a}}$ & $4.11^{b}$ & $5.05^{\mathrm{ab}}$ & $6.18^{b}$ & $*$ \\
\hline Monoterpenes & & $60.88^{b}$ & 58.09 ab & $62.07^{\mathrm{b}}$ & $53.90 \mathrm{ab}$ & $49.48^{\mathrm{a}}$ & * \\
\hline Sesquiterpenes & & $30.86^{b}$ & $29.82^{b}$ & $29.03^{b}$ & $34.56^{\mathrm{ab}}$ & $39.83^{a}$ & * \\
\hline Total & & 94.67 & 91.09 & 94.88 & 91.65 & 91.60 & \\
\hline
\end{tabular}

Notes: ${ }^{1}$ Retention indices; ${ }^{2}$ control sample; ${ }^{3}$ the level of significance: $n s=$ not significant, ${ }^{*}=$ significance level at $5 \%$; means designated by the different letters are significantly different.

Table 7. The chemical composition of the EO of basil.

\begin{tabular}{|c|c|c|c|c|c|c|c|}
\hline \multirow[b]{2}{*}{ Component } & \multicolumn{7}{|c|}{ Elicitors } \\
\hline & RI $^{1}$ & $0.1 \mathrm{mM}$ Меја & $2 \mathrm{mM}$ MeJa & $0.1 \mathrm{mM} \mathrm{SA}$ & $2 \mathrm{mM} S A$ & $C^{2}$ & Sign. ${ }^{3}$ \\
\hline 1,8-Cineole & 1034 & $6.64^{\mathrm{ab}}$ & $7.83^{a b}$ & $4.78^{a}$ & $7.79 \mathrm{ab}$ & $9.33^{\mathrm{b}}$ & * \\
\hline Linalool & 1097 & $50.07^{\mathrm{a}}$ & $53.58^{\mathrm{a}}$ & $46.24^{\mathrm{a}}$ & $51.28^{a}$ & $46.74^{\mathrm{a}}$ & ns \\
\hline Camphor & 1144 & $0.56^{\mathrm{a}}$ & $0.57^{\mathrm{a}}$ & $0.45^{\mathrm{a}}$ & $0.24^{\mathrm{a}}$ & $0.60^{\mathrm{a}}$ & ns \\
\hline$\alpha$-Terpineol & 1189 & $0.98^{\mathrm{a}}$ & $1.04^{\mathrm{a}}$ & $1.10^{\mathrm{a}}$ & $1.14^{\mathrm{a}}$ & $1.15^{\mathrm{a}}$ & ns \\
\hline Iso-bornyl acetate & 1281 & $1.55^{\mathrm{b}}$ & $1.98^{\mathrm{c}}$ & $1.71^{b c}$ & $1.14^{\mathrm{a}}$ & $1.69 \mathrm{bc}$ & $*$ \\
\hline Eugenol & 1361 & $2.94^{\mathrm{a}}$ & $2.54^{\mathrm{a}}$ & $3.04^{\mathrm{a}}$ & $3.19^{\mathrm{a}}$ & $2.11^{\mathrm{a}}$ & ns \\
\hline$\beta$-Elemene & 1391 & $1.00^{a b}$ & $0.78^{\mathrm{a}}$ & $1.20^{b}$ & $0.86^{\mathrm{ab}}$ & $0.75^{\mathrm{a}}$ & * \\
\hline trans- $\alpha$-Bergamotene & 1437 & $3.52^{\mathrm{a}}$ & $4.71^{\mathrm{b}}$ & $7.05^{c}$ & $5.40^{b}$ & $5.70^{b}$ & * \\
\hline$\alpha$-Guaiene & 1439 & $0.91^{b}$ & $0.69^{a b}$ & $0.92^{b}$ & $0.74^{\mathrm{ab}}$ & $0.64^{\mathrm{a}}$ & * \\
\hline$\alpha$-Humulene & 1454 & $0.75^{b}$ & $0.56^{\mathrm{a}}$ & $0.71 \mathrm{ab}$ & $0.62^{a b}$ & $0.58^{\mathrm{a}}$ & * \\
\hline (+)-epi-Bicyclosesquiphellandrene & 1464 & $0.64^{\mathrm{ab}}$ & $0.49^{\mathrm{a}}$ & $0.73^{\mathrm{b}}$ & $0.59^{a b}$ & $0.64^{\mathrm{ab}}$ & * \\
\hline Germacrene D & 1482 & $2.82^{\mathrm{ab}}$ & $2.30^{\mathrm{a}}$ & $3.55^{\mathrm{b}}$ & $2.69^{a b}$ & $2.39^{\mathrm{a}}$ & * \\
\hline
\end{tabular}


Table 7. Cont.

\begin{tabular}{|c|c|c|c|c|c|c|c|}
\hline \multirow[b]{2}{*}{ Component } & \multicolumn{7}{|c|}{ Elicitors } \\
\hline & RI $^{1}$ & $0.1 \mathrm{mM}$ Meja & $2 \mathrm{mM}$ MeJa & $0.1 \mathrm{mM} \mathrm{SA}$ & $2 \mathrm{mM} S A$ & $C^{2}$ & Sign. $^{3}$ \\
\hline Bicyclogermacrene & 1497 & $1.08^{\mathrm{b}}$ & $0.57^{\mathrm{a}}$ & $1.10^{\mathrm{b}}$ & $0.80^{\mathrm{ab}}$ & $0.64^{\mathrm{a}}$ & ** \\
\hline$\alpha$-Bulnesene & 1506 & $2.87^{\mathrm{a}}$ & $2.24^{\mathrm{a}}$ & $2.95^{\mathrm{a}}$ & $2.48^{\mathrm{a}}$ & $2.15^{\mathrm{a}}$ & ns \\
\hline cis- $\gamma$-Cadinene & 1515 & $3.02^{b}$ & $2.18^{a}$ & $3.34^{b}$ & $2.99^{b}$ & $2.93^{\mathrm{ab}}$ & * \\
\hline$\delta$-Cadinene & 1524 & $0.65^{a b}$ & $0.51^{\mathrm{a}}$ & $0.88^{b}$ & $0.69^{a b}$ & $0.74^{\mathrm{ab}}$ & $* *$ \\
\hline Spathulenol & 1584 & $1.25^{b}$ & $0.82^{a}$ & $1.01 \mathrm{ab}$ & $0.95^{\mathrm{a}}$ & $0.91^{\mathrm{a}}$ & * \\
\hline 1,10-di-epi-Cubenole & 1621 & $1.30^{\mathrm{a}}$ & $1.11^{\mathrm{a}}$ & $1.36^{\mathrm{a}}$ & $1.18^{\mathrm{a}}$ & $1.36^{\mathrm{a}}$ & ns \\
\hline Tau-cadinol & 1644 & $9.42^{\mathrm{a}}$ & $8.01^{\mathrm{a}}$ & $9.66^{\mathrm{a}}$ & $9.34^{\mathrm{a}}$ & $9.34^{\mathrm{a}}$ & ns \\
\hline Monoterpenes & & $62.75^{a b}$ & $67.54^{b}$ & $57.32^{\mathrm{a}}$ & $64.78^{a b}$ & $61.62^{a b}$ & $*$ \\
\hline Sesquiterpenes & & $29.23^{a b}$ & $24.98^{a}$ & $34.46^{\mathrm{b}}$ & $29.32^{a b}$ & $28.77^{a b}$ & * \\
\hline Total: & & 91.97 & 92.67 & 91.78 & 94.10 & 90.38 & \\
\hline
\end{tabular}

Notes: ${ }^{1}$ Retention indices; ${ }^{2}$ control sample; ${ }^{3}$ the level of significance: $\mathrm{ns}=$ not significant, ${ }^{*}=$ significance level at $5 \%, * *=$ significance level at $1 \%$; Values designated by the different letters are significantly different.

\subsection{Total Phenolic Content}

The effect of treatments on the total phenolic content (TPC) of the four species is demonstrated in the bar graph below (Figure 3). TPC is expressed by mg GAE/g d.w. of the. After the treatments, significant differences were observed. The TPC of marjoram ranged between 200 and $360 \mathrm{mg} \mathrm{GAE/g} \mathrm{d.w.,} \mathrm{the} \mathrm{lowest} \mathrm{one} \mathrm{with} \mathrm{foliar} \mathrm{application} \mathrm{of}$ $2 \mathrm{mM}$ of MeJa and the highest one with $0.1 \mathrm{mM}$ of SA. This latter treatment increased the TPC by approximately $36 \%$ compared to the control. Various studies have mentioned the elicitation effect of MeJa and JA in enhancing bioactive compounds including phenolic compounds and flavonoids in different plant species, such as butter lettuce (Lactuca sativa L.), melon (Cucumis melo), and Saint John's wort (Hypericum perforatum), whether applied in vivo or in vitro [41-43]. However, Zlotek observed the failure of MeJa to change the TPC especially in marjoram [44]. In our study, the $0.1 \mathrm{mM}$ and $2 \mathrm{mM}$ of MeJa decreased the content by approximately $27 \%$ and $31 \%$, respectively.

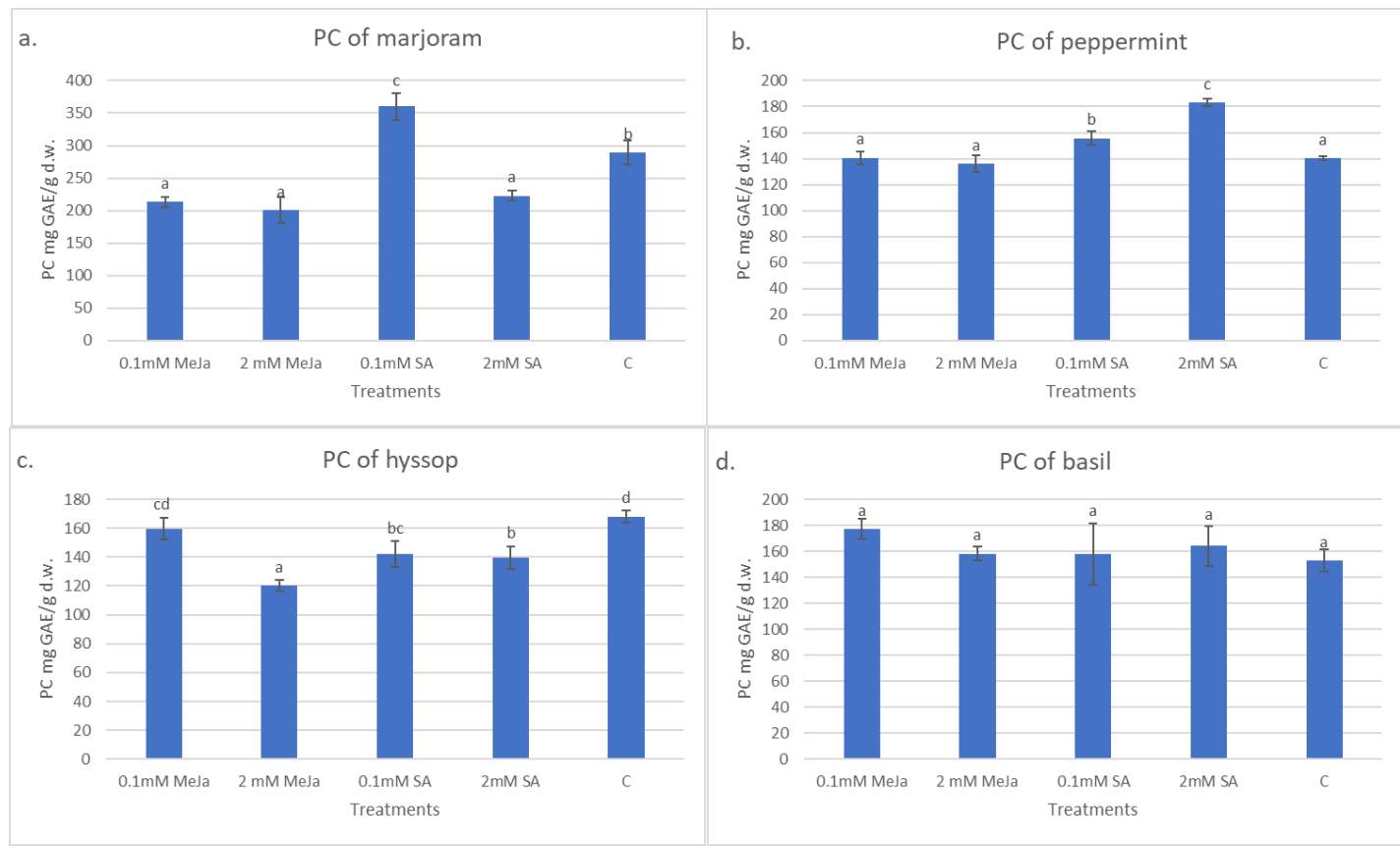

Figure 3. The effect of MeJa and SA on TPC of the subject species; (a) marjoram, (b) peppermint, (c) hyssop, and (d) basil; Data are expressed as means \pm SD; means with different letters are significantly different $(p<0.05)$. 
In the case of peppermint, both SA dosages elevated the TPC, while treatment with MeJa did not result in any significant changes. The effect of SA on the phenolic accumulation in peppermint was also previously observed, where increasing the TPC by $65 \%$ and $31 \%$ was reached after treatment with the dosages of 0.5 and $2 \mathrm{mM}$, respectively [45].

As for hyssop and basil, the applied elicitors had contradictory results. All the treatments decreased the TPC in hyssop significantly, and the sample treated with $2 \mathrm{mM}$ of MeJa was lower than the control by $28 \%$. However, in basil, the treatments increased the TPC and the concentration $0.1 \mathrm{mM}$ of MeJa was the most effective. The latter findings are partly in agreement with Kim et al. [46] where the $0.1 \mathrm{mM}$ of MeJa could not increase the TPC in basil, but a higher dosage $(0.5 \mathrm{mM}$ of MeJa) was effective.

\subsection{Antioxidant Capacity}

The effect of treatments on the AC of the four species (expressed by mg AAE/g d.w.) is demonstrated in Figure 4. The results closely correlate with the TPC data in all species and for all treatments. For both marjoram and hyssop, the treatments decreased the AC except for the lower dosage of SA treatment in marjoram, which showed a $50 \%$ stronger activity than the control. In hyssop, each treatment decreased the AC except for the lower dosage of MeJa. This is in contradiction to several reports about the effect of MeJa in elevating the AC; not only in healthy plants but also in plants subjected to water deficit stress, where this phytohormone presumably enhances the protection mechanisms $[42,47,48]$.

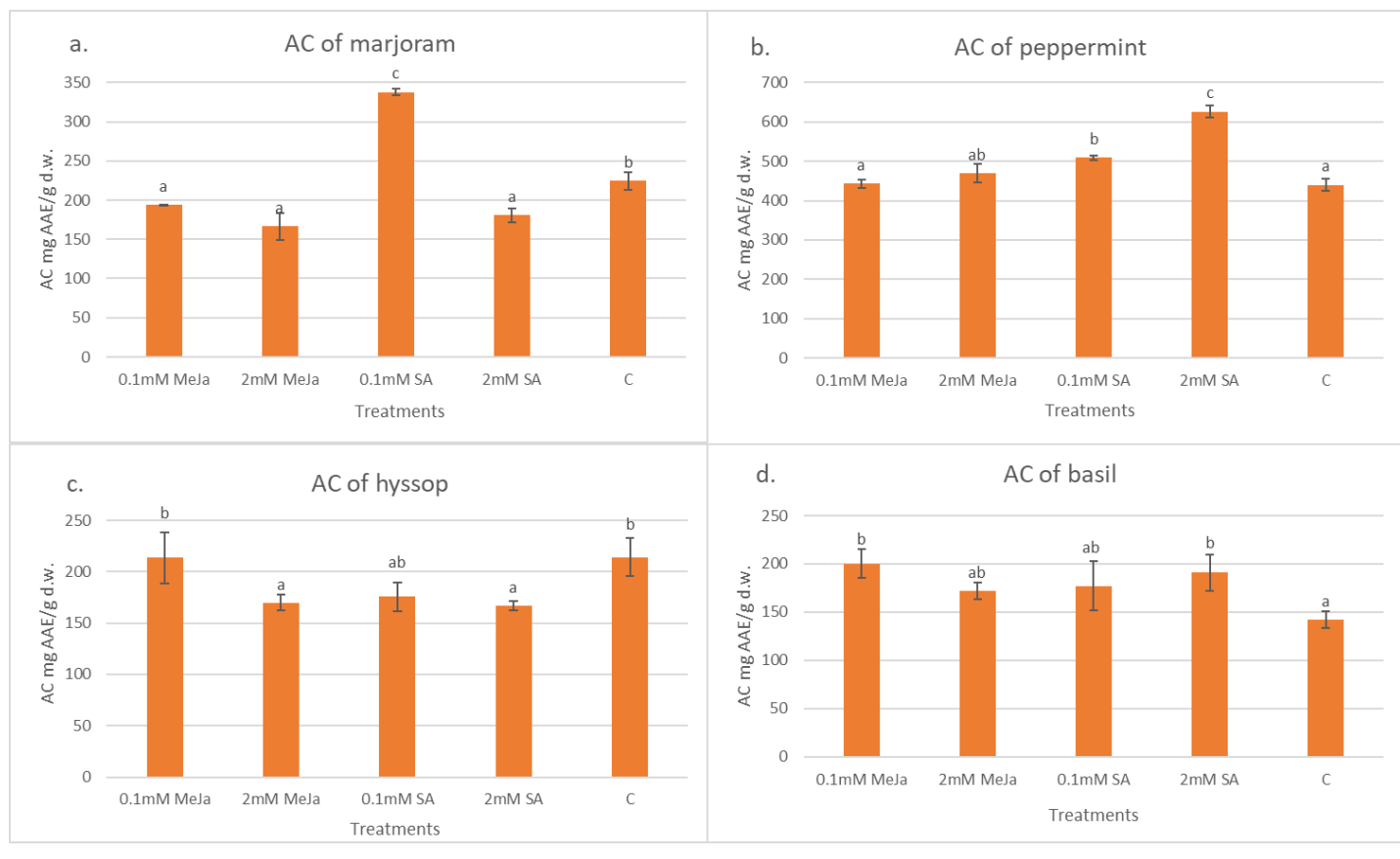

Figure 4. The effect of MeJa and SA on the antioxidant activity of the subject species; (a) marjoram, (b) peppermint, (c) hyssop, and (d) basil; Data are expressed as means \pm SD; means with different letters are significantly different $(p<0.05)$.

Similarly, to these publications, in the case of peppermint, both dosages of SA were able to increase the AC in our experiment also, where the $2 \mathrm{mM}$ dosage resulted in the highest activity. This result is similar to that of Figueroa Pérez et al. [45] where different dosages of SA ranging between 0.5 and $2 \mathrm{mM}$ increased the AC. As for MeJa treatments, no significant differences were registered.

SA is a plant hormone that plays a pivotal role in regulating physiological and biosynthetic processes. If applied exogenously, SA triggers a hypersensitive response by causing a temporary increase of reactive oxygen species (ROS) followed by phenolic compounds, biosynthesis and elevated antioxidant activity $[49,50]$. It was found that MeJa is effective 
only in basil for stimulating the accumulation of phenolic compounds and increasing AC. A considerable amount of literature supports the contribution of polyphenols in lowering the risk of health disorders, such as cancer, cardiovascular diseases, chronic inflammations, degenerative diseases, and diabetes. This is because of their strong antioxidant activity and ability to scavenge free radicals, thus reducing oxidative damage [51,52].

For basil, all treatments increased the AC but only $0.1 \mathrm{mM}$ of MeJa and $2 \mathrm{mM}$ of SA were significant, where they raised AC by $40 \%$ and $35 \%$, respectively. The results of Wang et al. [53] and Blanch et al. [54] support these findings, as they found that both SA and MeJa increased the AC in blackberries (Rubus sp.) and table grapes (Vitis vinifera).

\section{Conclusions}

The elicitors MeJa, and SA used in this research showed specific responses in each plant species, depending on the dosage applied and the parameter studied.

SA stimulated the EO accumulation in three model species. However, MeJa proved to be effective only in marjoram where the higher concentration significantly elevated the volatile production. In the case of basil, both elicitors induced contrasting reactions-the volatile accumulation was stopped and the EO content decreased.

SA also demonstrated a higher efficacy in altering the quantitative spectrum of the Eos of marjoram, peppermint and hyssop. While no significant change of the major components of basil $\mathrm{EO}$ was detected in consequence of SA and MeJa treatments. It may be of practical importance too, that some treatments-primarily those using SA-were able also to shift the ratios of total mono and sesquiterpenes significantly in all the species except peppermint.

Moreover, our results confirmed several earlier publications about the strong connection between the TPC and antioxidant activity. SA was successful in increasing these two parameters in all of the experimental species except hyssop.

The experiments demonstrated that elicitation is a potentially effective tool for influencing both the accumulation level and the quantitative spectrum of the volatiles. Besides, TPC and AC can be changed by means of well-established treatments. At the same time, it was found that the subject Lamiaceae species show different sensitivity to the applied concentrations of MeJa and SA. Concerning the EO content and composition, under the experimental conditions, marjoram showed the strongest reactions while basil was the least sensitive. In the context of phenolics and AC, however, basil showed higher sensitivity and more reactions and hyssop was less influenced. We were able to establish that elicitation in vivo is a gentle tool in influencing the accumulation of SMs in medicinal plants; however, the result is dependent not only on the elicitor compound and its concentrations but also on the target species and the type of accumulated molecules. Based on the presented first results, optimization of the treatments is suggested in further in vivo experiments.

Author Contributions: W.K.: Study design, methodology, formal analysis, writing—original draft/ review and editing; P.R.: Methodology; B.G.: Methodology; É.Z.N.: Study design, methodology, review and editing, supervision. All authors have read and agreed to the published version of the manuscript.

Funding: This research was supported by the Ministry for Innovation and Technology within the framework of the Thematic Excellence Programme 2020 (TKP2020-IKA-12) and by EU-Erasmus+ EOHUB project (600873-EPP-1-2018-1ES-EPPKA2-KA).

Institutional Review Board Statement: Not applicable.

Informed Consent Statement: Not applicable.

Data Availability Statement: The data presented in this study are available within the article.

Conflicts of Interest: The authors declare no conflict of interest. 


\section{References}

1. Tamokou, J.D.D.; Mbaveng, A.T.; Kuete, V. Antimicrobial Activities of African Medicinal Spices and Vegetables; Elsevier Inc.: Amsterdam, The Netherlands, 2017; ISBN 9780128094419. [CrossRef]

2. Karpiński, T.M. Essential Oils of Lamiaceae Family Plants as Antifungals. Biomolecules 2020, 10, 103. [CrossRef] [PubMed]

3. Charles, D. Antioxidant Properties of Spices, Herbs and Other Sources; Springer: New York, NY, USA, 2012.

4. Saxena, D.; Jayant, S.K.; Soni, K.; Neekhra, K. Origanum majorana: A potential herb for functional food. Eur. J. Pharm. Med. Res. 2016, 3, 321-325.

5. Bina, F.; Rahimi, R. Sweet Marjoram: A Review of Ethnopharmacology, Phytochemistry, and Biological Activities. J. Evid. Based. Complementary Altern. Med. 2017, 22, 175-185. [CrossRef]

6. Schmidt, E.; Bail, S.; Buchbauer, G.; Stoilova, I.; Krastanov, A.; Stoyanova, A.; Jirovetz, L. Chemical Composition, Olfactory Evaluation and Antioxidant Effects of the Essential oil of Origanum majorana L. from Albania. NPC Nat. Prod. Commun. 2008, 3 , 1051-1056. [CrossRef]

7. Mahendran, G.; Rahman, L.U. Ethnomedicinal, phytochemical and pharmacological updates on Peppermint (Mentha $\times$ piperita L.)-A review. Phyther. Res. 2020, 34, 2088-2139. [CrossRef]

8. Brown, N.; John, J.A.; Shahidi, F. Polyphenol composition and antioxidant potential of mint leaves. Food Prod. Process. Nutr. 2019, 1, 1-14. [CrossRef]

9. Bodalska, A.; Kowalczyk, A.; Włodarczyk, M.; Fecka, I. Analysis of polyphenolic composition of a herbal medicinal productpeppermint tincture. Molecules 2020, 25, 69. [CrossRef]

10. Németh-Zámbori, É.; Rajhárt, P.; Inotai, K. Effect of genotype and age on essential oil and total phenolics in hyssop (Hyssopus officinalis L.). Artic. J. Appl. Bot. Food Qual. 2017, 90, 25-30. [CrossRef]

11. Zawilak, G. The chemical composition of essential hyssop oil depending on plant growth stage. Acta Sci. Pol. Hortorum Cultus 2013, 12, 161-170.

12. Pushpangadan, P.; George, V. Basil. In Handbook of Herbs and Spices, 2nd ed.; Elsevier Inc.: Amsterdam, The Netherlands, 2012; Volume 1, pp. 55-72, ISBN 9780857095671. [CrossRef]

13. Kwee, E.M.; Niemeyer, E.D. Variations in phenolic composition and antioxidant properties among 15 basil (Ocimum basilicum L.) cultivars. Food Chem. 2011, 128, 1044-1050. [CrossRef]

14. Halder, M.; Sarkar, S.; Jha, S. Elicitation: A biotechnological tool for enhanced production of secondary metabolites in hairy root cultures. Eng. Life Sci. 2019, 19, 880. [CrossRef]

15. Khan, M.I.R.; Fatma, M.; Per, T.S.; Anjum, N.A.; Khan, N.A. Salicylic acid-induced abiotic stress tolerance and underlying mechanisms in plants. Front. Plant Sci. 2015, 6, 1-17. [CrossRef] [PubMed]

16. Bücker-Neto, L.; Paiva, A.L.S.; Machado, R.D.; Arenhart, R.A.; Margis-Pinheiro, M. Interactions between plant hormones and heavy metals responses. Genet. Mol. Biol. 2017, 40, 373-386. [CrossRef] [PubMed]

17. Klessig, D.F.; Choi, H.W.; Dempsey, D.A. Systemic acquired resistance and salicylic acid: Past, present, and future. Mol. Plant-Microbe Interact. 2018, 31, 871-888. [CrossRef] [PubMed]

18. Nabi, N.; Singh, S.; Saffeullah, P. Responses of in vitro cell cultures to elicitation: Regulatory role of jasmonic acid and methyl jasmonate: A review. Vitr. Cell. Dev. Biol.-Plant 2021, 57, 341-355. [CrossRef]

19. Van Den Dool, H.; Kratz, P.D. A generalization of the retention index system including linear temperature programmed gas-liquid partition chromatography. J. Chromatogr. 1963, 11, 463-471. [CrossRef]

20. Adams, R. Identification of Essential oil Components by Gas Chromatography/Mass Spectrometry; Allured Publishing Corporation: Chicago, IL, USA, 2007.

21. Singleton, V.L.; Rossi, J.A. Colorimetry of total phenolics with phosphomolybdic-phosphotungstic acid reagents. Am. J. Enol. Vitic. 1965, 16, 144-158.

22. Benzie, I.F.F.; Strain, J.J. The Ferric Reducing Ability of Plasma (FRAP) as a Measure of "Antioxidant Power": The FRAP Assay. Anal. Biochem. 1996, 239, 70-76. [CrossRef]

23. Ghasemi, A.; Ab, P.; Rahimmalek, M.; Elikaei-Nejhad, L.; Hamedi, B.; Pirbalouti, A.G. Essential oil compositions of summer savory under foliar application of jasmonic acid and salicylic acid Essential oil compositions of summer savory under foliar application of jasmonic acid and salicylic acid. J. Essent. Oil Res. 2014, 26, 342-347. [CrossRef]

24. Ashrafi, M.; Ghasemi Pirbalouti, A.; Rahimmalek, M.; Hamedi, B. Effect of foliar application of Jasmonic Acid (JA) on essential oil yield and its compositions of Thymus daenensis Celak. J. Med. Herbs 2012, 3, 75-80.

25. Yadegari, M. Foliar application effects of salicylic acid and jasmonic acid on the essential oil composition of Salvia officinalis Turkish J. Biochem. 2018, 43, 417-424. [CrossRef]

26. Fard, F.R.; Omidbaigi, R.; Sharifi, M.; Sefidkon, F. Effect of methyl jasmonate on essential oil content and composition of Agastache foeniculum. J. Med. Plants Res. 2012, 6, 5701-5705. [CrossRef]

27. Gharib, F.A.E. Effect of Salicylic Acid on the Growth, Metabolic Activities and Oil Content of Basil and Marjoram. Int. J. Agric. Biol. 2006, 8, 485-492.

28. Gharib, F.A.; Moussa, L.A.; Massoud, O.N. Effect of Compost and Bio-fertilizers on Growth, Yield and Essential Oil of Sweet Marjoram (Majorana hortensis) Plant. Int. J. Agric. Biol. J. Agric. Biol. 2008, 10, 381-388. 
29. Commission, E. Regulation (EC) No 1334/2008 of the european parliament and of the council of 16 December 2008 on flavourings and certain food ingredients with flavouring properties for use in and on foods and amending Council Regulation (EEC) No 1601/91, Regulations (EC). Off. J. Eur. Union 2008, 50, 34-50.

30. Ahmad, B.; Jaleel, H.; Sadiq, Y.; Khan, M.M.A.; Shabbir, A. Response of exogenous salicylic acid on cadmium induced photosynthetic damage, antioxidant metabolism and essential oil production in peppermint. Plant Growth Regul. 2018, 86, 273-286. [CrossRef]

31. Maffei, M.; Scannerini, S. UV-B Effect on Photomorphogenesis and Essential Oil Composition in Peppermint (Mentha piperita L.). J. Essent. Oil Res. 2000, 12, 523-529. [CrossRef]

32. Fraternale, D.; Ricci, D.; Epifano, F.; Curini, M. Composition and antifungal activity of two essential oils of hyssop (Hyssopus officinalis L.). J. Essent. Oil Res. 2004, 16, 617-622. [CrossRef]

33. Sharmeen, J.B.; Mahomoodally, F.M.; Zengin, G.; Maggi, F. Essential oils as natural sources of fragrance compounds for cosmetics and cosmeceuticals. Molecules 2021, 26, 666. [CrossRef]

34. Gorni, P.H.; Pacheco, A.C.; Silva, J.F.A.; Moreli, R.R.; Spera, K.D.; Silva, R.M.G. Plant elicitation with salicylic acid increases bioactive compounds content and antioxidant activity in the infusion of Achillea millefolium L. Biosci. J. 2019, 35, $289-295$. [CrossRef]

35. Sarrou, E.; Chatzopoulou, P.; Dimassi-Theriou, K.; Therios, I.; Koularmani, A. Effect of melatonin, salicylic acid and gibberellic acid on leaf essential oil and other secondary metabolites of bitter orange young seedlings. J. Essent. Oil Res. 2015, 27, 487-496. [CrossRef]

36. Da Silva, S.; Barbosa Moreira, C.; Apparecida Esquibel, M.; Aguiar Da, R.; Gil, S.S.; Alberto, C.; Riehl, S.; Sato, A. Effect of salicylic acid on essential oil compounds of Melissa officinalis in vitro plants. Agropecuária Técnica 2014, 35, 178-184.

37. Pirbalouti, A.; Gorgij, A.; Rahimmalek, M.; Hamedi, B. Phytochemical response of hyssop (Hyssopusofficinalis L.) to foliar application of jasmonic acid. J. Herb. Drugs 2013, 4, 7-14.

38. Deschamps, C.; Simon, J.E. Terpenoid Essential Oil Metabolism in Basil (Ocimum basilicum L.) Following Elicitation. J. Essent. Oil Res. 2006, 18, 618-621. [CrossRef]

39. Talebi, M.; Moghaddam, M.; Pirbalouti, A.G. Methyl jasmonate effects on volatile oil compounds and antioxidant activity of leaf extract of two basil cultivars under salinity stress. Acta Physiol. Plant. 2018, 40, 1-11. [CrossRef]

40. Trettel, J.R.; Gazim, Z.C.; Gonçalves, J.E.; Stracieri, J.; Magalhães, H.M. Effects of copper sulphate (CuSO4) elicitation on the chemical constitution of volatile compounds and the in vitro development of Basil. Sci. Hortic. 2018, 234, 19-26. [CrossRef]

41. Złotek, U.; Świeca, M.; Jakubczyk, A. Effect of abiotic elicitation on main health-promoting compounds, antioxidant activity and commercial quality of butter lettuce (Lactuca sativa L.). Food Chem. 2014, 148, 253-260. [CrossRef]

42. Nafie, E.; Hathout, T.; Al Mokadem, A.S. Jasmonic acid elicits oxidative defense and detoxification systems in Cucumis melo L. cells. Brazilian J. Plant Physiol. 2011, 23, 161-174. [CrossRef]

43. Gadzovska, S.; Maury, S.; Delaunay, A.; Spasenoski, M.; Joseph, C.; Hagège, D. Jasmonic acid elicitation of Hypericum perforatum L. cell suspensions and effects on the production of phenylpropanoids and naphtodianthrones. Plant Cell. Tissue Organ Cult. 2007, 89, 1-13. [CrossRef]

44. Złotek, U. Effect Of Jasmonic Acid and yeast extract elicitation on low-molecular antioxidants and antioxidant activity of Marjoram (Origanum majorana L.). Acta Sci. Pol. Technol. Aliment. 2017, 16, 371-377. [CrossRef]

45. Figueroa Pérez, M.G.; Rocha-Guzmán, N.E.; Mercado-Silva, E.; Loarca-Piña, G.; Reynoso-Camacho, R. Effect of chemical elicitors on peppermint (Mentha piperita) plants and their impact on the metabolite profile and antioxidant capacity of resulting infusions. Food Chem. 2014, 156, 273-278. [CrossRef] [PubMed]

46. Kim, H.J.; Chen, F.; Wang, X.; Rajapakse, N.C. Effect of methyl jasmonate on secondary metabolites of sweet basil (Ocimum basilicum L.). J. Agric. Food Chem. 2006, 54, 2327-2332. [CrossRef] [PubMed]

47. Bandurska, H.; Stroiński, A.; Kubiś, J. The effect of jasmonic acid on the accumulation of ABA, proline and spermidine and its influence on membrane injury under water deficit in two barley genotypes. Acta Physiol. Plant. 2003, 25, 279-285. [CrossRef]

48. Abdi, G.; Shokrpour, M.; Karami, L.; Salami, S.A. Prolonged water deficit stress and methyl jasmonate-mediated changes in metabolite profile, flavonoid concentrations and antioxidant activity in peppermint (Mentha $\times$ piperita L.). Not. Bot. Horti Agrobot. Cluj-Napoca 2019, 47, 70-80. [CrossRef]

49. Borsani, O.; Valpuesta, V.; Botella, M.A. Evidence for a Role of Salicylic Acid in the Oxidative Damage Generated by NaCl and Osmotic Stress in Arabidopsis Seedlings. Plant Physiol. 2001, 126, 1024-1030. [CrossRef] [PubMed]

50. Aberg, B. Plant growth regulators. XLI. Monosubstituted benzoic acids. Swedish J. Agric. Res. 1981, 11, 93-105.

51. Tsao, R. Chemistry and Biochemistry of Dietary Polyphenols. Nutrients 2010, 2, 1231. [CrossRef]

52. Scalbert, A.; Johnson, I.T.; Saltmarsh, M. Polyphenols: Antioxidants and beyond. Am. J. Clin. Nutr. 2005, 81, 215S-217S. [CrossRef]

53. Wang, S.Y.; Bowman, L.; Ding, M. Methyl jasmonate enhances antioxidant activity and flavonoid content in blackberries (Rubus sp.) and promotes antiproliferation of human cancer cells. Food Chem. 2008, 107, 1261-1269. [CrossRef]

54. Blanch, G.P.; Gómez-Jiménez, M.C.; del Castillo, M.L.R. Exogenous Salicylic Acid Improves Phenolic Content and Antioxidant Activity in Table Grapes. Plant Foods Hum. Nutr. 2020, 75, 177-183. [CrossRef] 